\title{
Introduction: Language, Identity, and Ideology in Ukrainian Media
}

Volodymyr Kulyk

Institute of Political and Ethnic Studies, National Academy of Sciences of Ukraine

\section{Alla Nedashkivska}

University of Alberta

$\mathrm{I}^{\mathrm{n}}$

n contemporary societies, mass media are increasingly important as a

means of both communication and discursive representation. Media interaction is one of the main practices where people use language to learn about others and tell about themselves. Hence, it is one of the key sites for constructing identities and articulating ideologies. As technological means of mediated communication evolve, so too do ways in which people use them to exchange their beliefs about themselves and the world, and, with just a little delay, methods scholars employ to study these exchanges. It is therefore no wonder that studies of media communication and representation is one of the most vibrant fields within the social sciences and the humanities. Apart from those specializing in it, media attract scholars primarily working in linguistics, anthropology, sociology, political science, history, and other disciplines.

Within Ukrainian studies, this field has not yet received the attention it deserves, so by publishing a special issue with an explicit focus on the media we hope to help obviate this shortcoming. In our call for proposals, we encouraged scholars from various countries and disciplines to engage in the critical examination of language use, identity construction, and ideological representations in diverse practices of mass media in Ukraine and the Ukrainian diaspora. We did not prioritize proposals focusing on the present over those dealing with the past or analyses of the "new" media over more traditional kinds. Yet we were not surprised to find that most of the scholars who responded to our call were interested in recent and novel media practices, first and foremost communication in social media. Equally understandable is a keen attention to the effects of the Euromaidan and the Russian military intervention. These two phenomena are of enormous importance to Ukraine's present and future and have been extensively covered by various media organizations and discussed by ordinary citizens on Internet forums and social networking services. At the same time, texts presented in this issue shed new light on some of the core topics of Ukrainian studies, including Ukraine's positioning between the East and the West, 
relations between different ethnolinguistic groups, and the interaction between Ukraine and its diaspora in different parts of the world. The articles analyze how media texts portray, construct, negotiate, promote, or downplay certain identities, allegiances, and power relationships. The discussions of belonging, that is, inclusion in and exclusion from certain discourses of social, ethnic, and language groups, are particularly prominent in the studies presented in this issue.

In the first two articles, Roman Horbyk and Holger Kusse write about verbal aggression in media discourse, demonstrating the diverse constructions of the "self" and the "other" in times of conflict by holders of different ideological positions in contemporary Ukraine. Horbyk analyzes texts from 2010-12, the time of electoral campaigns during the presidency of Viktor Ianukovych. Kusse focuses on media texts from 2014 onward, specifically those that exhibit language aggression during and following the Maidan revolution.

Taking the perspectives of social and ethnolinguistic identity theories and the feminist theory of hate speech, Horbyk applies critical discourse analysis to study readers' discussions of language-related articles published on Ukraine's leading news website Ukrains'ka Pravda (Ukrainian Truth). By demonstrating the abundance of hate speech in readers' comments on language issues in Ukraine through the fierce mutual "othering" of the Ukrainian-speaking and Russian-speaking Ukrainians, Horbyk shows conflicting discourses on language and identity. He concludes that although verbal combat and hate-speech-laden discourses on language and belonging point to aggressiveness, and perhaps demonstrate undemocratic behaviour in anonymized communication online, they, in fact, display a variety of group allegiances and indicate acute social issues, even preparing "the ground for more civilized, consensual, and democratic interactions" (Horbyk, this issue).

Kusse investigates aggression in the construction of arguments related to the Russian-Ukrainian conflict since 2014. The data are rich, representing various types of discourse: political maps, official political discourse, visual propaganda, and poetry. Kusse studies both monomodal and multimodal texts, showcasing how different semiotic means are utilized to generate aggressive implications of seemingly argumentative representations of the conflict. Specifically, he analyzes several political maps, focusing on the representation of Ukraine by the Russian media with their aggressive message of the "non-existence" of Ukraine. Kusse also explores the intertextual connections of argumentation and aggression through the analysis of poetry. He devotes a great deal of attention to Anastasiia Dmytruk's poem "Nikogda my ne budem brat'iami" ("Never ever we will be brothers"), as well as the multitude of responses this poem has received on social media. By carefully studying these texts, Kusse builds his own theory 
of argumentation and aggression and deconstructs the "accepted" binary opposition of the two phenomena, thus convincing his readers that argumentation and aggression are intertwined.

Belonging, attitudes, and identity are the overarching concepts in the articles by Volodymyr Kulyk, Ivan Kozachenko, Alla Nedashkivska, and Ivan Basenko. All four studies show how dramatic political events in Ukraine throughout different time periods influenced these concepts and had a profound impact on how they were shaped and (re)constructed. Kulyk focuses on post-Maidan Ukrainian social media, which he views as vibrant sites of identity performance and construction. Both Kozachenko and Nedashkivska analyze current discourses in the diaspora(s) that demonstrate representations of belonging, associations, and attitudes, displaying also the transformations taking place in diasporic communities. Basenko takes the discussion back to the World War I period, studying the Russian language media manipulations in constructions of the national image of Ukraine and Ukrainians.

Examining social media, Kulyk stresses the vivid complexity of ethnolinguistic identities, language attitudes, and perceptions about language in post-Euromaidan Ukraine. By analyzing the posts of twelve prominent pro-Maidan personalities that pertain to a perceived belonging to a particular language or ethnic group, he delves into questions of the inclusion or exclusion of Ukraine's Russian-speakers in the imagined national Ukrainian "self." Kulyk lucidly demonstrates contrasting and conflicting ideologies in the presentation of the national "self" and the internal "other" in social media discourse, with language playing a prominent role in this conflict. His analysis clearly displays the plurality of and opposition to perceptions about language and national belonging, in particular the role of the Ukrainian language in the imagined national "self."

Kozachenko analyzes symbolic representations of the "homeland" by Ukrainian diasporas in five countries (Canada, the United Kingdom, Germany, Hungary, and the Czech Republic) and explores how these representations are being shaped by the dramatic events taking place in Ukraine. The focus is on "civic" and "ethnic" elements as seen in the three main themes: memory and national identity, languages and ethnicity, and regional identities. Like Kulyk, Kozachenko points to the complexity, plurality, and opposition in the studied representations. By distinguishing between the "old" and the "new" (post-2014) diasporic communities, he speaks of the visible divide between them. Overall, the "old" communities display more "ethnic" elements of their national belonging and the "new" communities showcase more "civic" aspects of Ukrainian nation-building. At the same time, Kozachenko points to transitions whereby the "old" diasporas change their presentations of the "homeland" by including the Russianspeaking Ukrainians who identify strongly with Ukraine as their "authentic 
homeland." Moreover, in their currently shifting representations of national belonging, the "old" diasporas are shown to be more inclusive of eastern and southern regions of Ukraine. Kozachenko concludes that now (compared to the recent past) the studied diasporas display more recognition of ethnolinguistic and regional diversity, underscoring the inclusive "civic" Ukrainian identity.

Nedashkivska combines the study of language attitudes with the examination of language practices as observed in social media interactions and as reported by participants in her study. Like Kozachenko, she focuses on the newest diaspora in Canada and illustrates their evident transformations. In the context of the diasporic community studied, Nedashkivska connects language practices and beliefs about language(s) to issues of identity construction and negotiation. She uses the language practices of members of the diasporic community, as well as their discourse about language to discuss how the speakers, through these practices and beliefs, position themselves in specific associations and disassociations. Nedashkivska's study demonstrates that in the diaspora the Ukrainian language indexes the community and thus serves as its central language, or the "language on display," regardless of participants' everyday language practices. (In a similar vein, Kozachenko terms Ukrainian as the "official" language of the diasporic communities.) The study highlights the acuteness of the language question and language attitudes, as well as shifts in language practices and language ideologies in the studied diasporic community.

In contrast to the authors discussed above, Basenko brings a historical perspective to the debate on media and its discursive representations. By studying media texts from 1914-18, he analyzes Russian language newspapers of different political and ideological orientations and demonstrates their overreaching attitudes toward Ukrainian national selfdetermination. Basenko's findings show that despite different political orientations, the Kyiv Russian-language media projected Ukrainians as members of the imagined all-Russian nation and a united Russian state, thereby denying any substantiality of the Ukrainian nation and thus rejecting claims for its independent state. He argues that in the context of World War I, the image of a German enemy was employed by the media to discredit a distinct Ukrainian identity and to downgrade the Ukrainian national movement. The denial of a separate "self" in the early twentieth century media discourses examined by Basenko echoes the above-discussed findings pertaining to the current media in Ukraine at a time of Russian aggression.

While dealing with a range of discursive practices and ideological effects of media in Ukraine and diaspora, most of the authors in this issue focus their analysis on the texts rather than on the processes of their production and consumption, or, for interactive media, on participants' textual contributions 
rather than on the reception of each other's messages. Although Kozachenko and Nedashkivska conducted interviews in the diasporic communities they studied, more ethnographic work in various sociocultural contexts is needed to obtain an adequate understanding of the impact of media discourses on their audiences. While studies in this issue feature ethnic, linguistic, and national identities, an examination of media articulation and manifestation of other identities defined by characteristics from gender to generation to lifestyle would be no less interesting. Moreover, comparative analyses of different kinds of media would be in order, as well as comparisons of media practices in Ukraine and Ukrainian diasporas with those in other countries and their diasporic communities. As editors and contributors, we would be happy to see the publication of this issue encourage scholars in subfields of Ukrainian studies to pay more attention to various things media do. 